\title{
Microstructure and Leaching Characteristics of a Technetium Containing Metal Waste Form
}

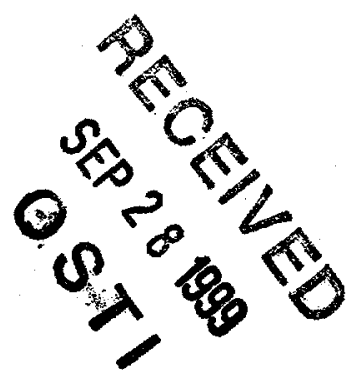

By:

\author{
S. G. Johnson, D. D. Keiser, M. Noy, T. O'Holleran and S. M. Frank \\ Nuclear Technology Division \\ Argonne National Laboratory \\ P. O. Box 2528 \\ Idaho Falls, ID 83403-2528
}

\begin{abstract}
The submitted manuscript has been created by the University of Chicago as Operator of Argonne National Laboratory ("Argonne") under Contract No. W-31-109-ENG-38 with the U.S. Department of Energy. The U.S. Government retains for itself, and others acting on its behalf, a paid-up, nonexclusive irrevocable woridwide license in said article to reproduce, prepare derivative works, distribute copies to the public, and perform pub. licly and display publicly, by or on behalf of the Government.
\end{abstract}

Conference Proceedings Material Research Society

Symposium: Scientific Basis for Waste Management XXII Fall Meeting

Boston, Massachusetts

November 30 - December 4, 1998

*Work supported by the U. S. Department of Energy, Office of Nuclear Energy, Science and Technology, and the Office of Environmental Management, under contract W-31-109-Eng-38. 


\section{DISCLAIMER}

This report was prepared as an account of work sponsored by an agency of the United States Government. Neither the United States Government nor any agency thereof, nor any of their employees, make any warranty, express or implied, or assumes any legal liability or responsibility for the accuracy, completeness, or usefulness of any information, apparatus, product, or process disclosed, or represents that its use would not infringe privately owned rights. Reference herein to any specific commercial product, process, or service by trade name, trademark, manufacturer, or otherwise does not necessarily constitute or imply its endorsement, recommendation, or favoring by the United States Government or any agency thereof. The views and opinions of authors expressed herein do not necessarily state or reflect those of the United States Government or any agency thereof. 


\section{DISCLAIMER}

Portions of this document may be illegible in electronic image products. Images are produced from the best available original document. 
MICROSTRUCTURE AND LEACHING CHARACTERISTICS OF A TECHNETIUM CONTAINING METAL WASTE FORM

\author{
S. G. JOHNSON, D. D. KEISER, M. NOY, T. O'HOLLERAN and S. M. FRANK \\ Argonne National Laboratory-West \\ P.O. 2528 \\ Idaho Falls, ID 83403
}

\title{
ABSTRACT
}

Argonne National Laboratory is developing an electrometallurgical treatment for spent fuel from the experimental breeder reactor II. A product of this treatment process is a metal waste form that incorporates the stainless steel cladding hulls, zirconium from the fuel and the fission products that are noble to the process, i.e., $\mathrm{Tc}, \mathrm{Ru}, \mathrm{Pd}, \mathrm{Rh}, \mathrm{Ag}$. The nominal composition of this waste form is stainless steel/15 wt\% zirconium/ 1-4 wt\% noble metal fission products. The behavior of technetium is of particular importance from a disposal point of view for this waste form due to its long half life, 2.14E5 years, and its mobility in groundwater. To address these concerns a limited number of spiked metal waste forms were produced containing Tc. These surrogate waste forms were then studied using scanning electron microscopy and selected leaching tests.

\section{INTRODUCTION}

Argonne National Laboratory is currently developing an electrometallurgical treatment for spent fuel to stabilize it prior to disposal in a geological repository. This process yields a uranium product, a ceramic waste form and a metal waste form[1,2]. The ceramic waste form, a sodalite/glass composite, contains the active fission products, i.e., alkali, alkaline earth, rare earth, transuranic, and halide elements. The metal waste form, a stainless steel/ zirconium alloy $(85: 15)$, contains the noble metals and some actinides. The noble metals for this process include: $\mathrm{Tc}, \mathrm{Ru}, \mathrm{Rh}, \mathrm{Nb}, \mathrm{Pd}, \mathrm{Ag}, \mathrm{Zr}$ and $\mathrm{Te}$. These noble metals are those that are not oxidized while being processed in the molten salt electrorefiner.

The focus of this study was to evaluate the metal waste form in regard to its behavior during long term immersion tests and to examine the microstructure. More specifically, three separate goals were to be accomplished by this work. First, the release rate for technetium was to be determined. Second, the effect of major and minor changes in the composition of the metal waste form on the release rates of technetium and uranium was to be established. Third, the microstructure of the alloy was to be examined. The first goal was accomplished by performing immersion tests on alloys consisting of only stainless steel, zirconium and technetium. The second goal was accomplished by testing specimens that had varying amounts of zirconium, noble metals and technetium.

The emphasis in the immersion tests was on technetium due to its importance in the realm of performance assessment of a geologic repository. Technetium is a long lived fission product and has tremendous mobility in water. 
The test method, the long-term pulsed flow test, was performed for time periods of over one year in length. This method employs a monolithic sample submerged at $90 \mathrm{C}$ with sampling occurring on a periodic basis of once every 1-4 weeks; an aliquot of leachate is taken, analyzed and replaced with fresh solution. Many of the tests discussed in this paper are still ongoing. The results to date are substantial and allow for certain conclusions regarding the durability of the metal waste to be made. This paper presents those results and conclusions.

\section{EXPERIMENTAL}

\section{Sample Preparation}

The metal alloy samples were cast in yttria crucibles under an argon atmosphere using a muffle furnace. The casting temperature was $1650 \mathrm{C}$. The argon atmosphere was used so as to ensure that the technetium would not oxidize and volatize. The composition of the various samples is stated in the text where appropriate. The elemental composition of the samples was confirmed via chemical analysis to ensure that the casting was successful. The middle section of the cast ingot was used for the immersion test. The surface preparation for the specimens prior to undergoing the immersion test was accomplished using one of two methods, either a metal file followed by 320 grit emery cloth or a Dremel tool with an abrasive wheel. The second method allowed for a more uniform finish on the samples. The hardness of the material was approximately $35 \mathrm{R}_{\mathrm{c}}$.

\section{Long-Term Pulsed Flow Test}

The long term pulsed flow immersion test was developed to evaluate the performance of high level waste forms under repository like conditions [3-5]. The robust nature of the metal waste form under development at ANL suggested that a long term test would be of use so this method was applied. The particulars of this test are as follows. A monolithic sample is prepared as described above and cleaned using several rinses in water and ethanol to remove any fines that may be left from the surface finishing technique applied. The sample is then placed into a metal Parr vessel of either stainless steel (304) or titanium construction. The leachant used is either ASTM type-I (DI) water or SJ-13 water. The chemical make-up of SJ-13 water is featured in Table I. The volume of water used is based on the geometrical surface area of the monolithic sample. No surface roughness factors are applied to surface area in respect to the quality of the surface finish. A typical value of the surface area to volume ratio is $20 \mathrm{~m}^{-1}$ or $50 \mathrm{~m}^{-1}$. This involves taking an approximately $1.25 \mathrm{~cm}$ diameter by $0.5 \mathrm{~cm}$ thick sample and placing it into $10-20 \mathrm{~mL}$ of water. The vessel is placed into a constant temperature oven at $90 \mathrm{C}$. It is removed on a periodic basis, allowed to cool, weighed and then sampled using a pipette. The aliquot of leachate removed is typically $5-10 \%$ of the total. The volume removed is replaced with fresh leachant and the vessel returned to the oven. The typical frequency of sampling is once every 1 4 weeks with the actual time out of the oven for sampling being less than 2 hours.

\section{Analysis Methods}

The leachate samples are analyzed for technetium. The technetium is determined using liquid scintillation. A $1 \mathrm{ml}$ sample is added to a quantity of Ultima Gold scintillation cocktail and counted. A blank and a standard are routinely counted as well. Precision for the analysis was typically $+/-10 \%$ or better. 
The SEM work was performed with a Zeiss DSM 960A digital scanning electron microscope. The energy dispersive detector was provided by Oxford Instruments.

Table I. The chemical make-up of SJ-13 water.

\begin{tabular}{|l|l|l|l|l|l|}
\hline Compound & $\begin{array}{l}\text { Conc. } \\
\mathrm{mg} / \mathrm{L}\end{array}$ & Compound & $\begin{array}{l}\text { Conc. } \\
\mathrm{mg} / \mathrm{L}\end{array}$ & Compound & $\begin{array}{l}\text { Conc. } \\
\text { mg/L }\end{array}$ \\
\hline $\mathrm{NaHCO}_{3}$ & 180 & $\mathrm{CaSO}_{4} \cdot 2 \mathrm{H}_{2} \mathrm{O}$ & 20 & $\mathrm{CaCl}_{2} \cdot 2 \mathrm{H}_{2} \mathrm{O}$ & 14 \\
\hline $\mathrm{KHCO}_{3}$ & 14 & $\mathrm{Mg} \mathrm{SO}_{4} \cdot 7 \mathrm{H}_{2} \mathrm{O}$ & 18 & $\mathrm{Ca}\left(\mathrm{NO}_{3}\right) \cdot 4 \mathrm{H}_{2} \mathrm{O}$ & 19 \\
\hline $\mathrm{SiO}_{2} \cdot \mathrm{H}_{2} \mathrm{O}$ & 84 & \multicolumn{3}{l}{} \\
\cline { 2 - 6 }
\end{tabular}

\section{Presentation of Results}

The amount of the analyte in the total is determined using one of methods described above. This is then used to calculate the normalized mass loss (NML) using the equation below.

$$
\mathrm{NML}=\left\{\mathrm{A}_{\mathrm{i}} /\left[\mathrm{m}_{\mathrm{f}} \times \mathrm{SA}\right]\right\}
$$

where,

$A_{i}=$ the amount of component $i$ in the solution in grams

$\mathrm{m}_{\mathrm{f}}=$ the mass fraction of component $\mathrm{i}$ in the sample being tested

$\mathrm{SA}=$ the geometrical surface area of the sample being tested

This quantity is then plotted versus the elapsed time in days. The slope of the plot would be the normalized release rate. The estimated forward reaction rate is obtained by evaluating the slope in the first few weeks where it is typically at its steepest. One can also evaluate the slope at longer time periods for comparison purposes.

\section{RESULTS AND DISCUSSION}

\section{Microstructural Characterization}

The typical microstructure observed for a $316 \mathrm{SS}-15 \mathrm{Zr}-2 \mathrm{Tc}$ alloy is presented in Figure 1. This figure shows the two major phases that comprise the alloy microstrucutre, viz. a $\mathrm{Zr}(\mathrm{Fe}, \mathrm{Cr}, \mathrm{Ni}) 2+\mathrm{x}$ phase and an Fe-solid solution phase. Most of the Fe-solid solution phase is ferrite, but some austenite was observed. Small amounts of an $(\mathrm{Fe}, \mathrm{Cr}, \mathrm{Ni}) 23 \mathrm{Zr} 6$ intermetallic phase were also detected in localized regions of the sample, along with some very small $\mathrm{Zr}$-rich and $\mathrm{Fe}$-rich phases that seem to be artifacts of the transformation of the $\mathrm{Zr}(\mathrm{Fe}, \mathrm{Cr}, \mathrm{Ni}) 2+\mathrm{x}$ phase to the $(\mathrm{Fe}, \mathrm{Cr}, \mathrm{Ni}) 23 \mathrm{Zr} 6$ intermetallic phase.

Point-to-point SEM/EDS and SEM/WDS analysis were used to characterize a top and bottom piece sliced from a $316 \mathrm{SS}-15 \mathrm{Zr}-2 \mathrm{Tc}$ alloy to determine phase compositions. The results are listed in Table II. The Tc is contained in all of the alloy phases and shows a slight preference for the ferrite and austenite phases. The higher level of Tc concentration in the bottom piece (due to the high density of Tc relative to the stainless steel components and zirconium) is reflected in the phase compositions. X-ray maps have been used to confirm that $\mathrm{Tc}, \mathrm{Fe}$, and $\mathrm{Cr}$ are enriched in the $\mathrm{Fe}$ solid solution phases, and $\mathrm{Zr}$ and $\mathrm{Ni}$ are enriched in the intermetallic phases. 




Figure 1. SEM backscattered electron image of a 316-15Zr-2Tc alloy. The two major alloy phases are shown. The bright phase is an $\mathrm{Zr}(\mathrm{Fe}, \mathrm{Cr}, \mathrm{Ni}) 2+\mathrm{x}$ type of phase and the dark phase is an Fe solid solution phase.

Table II. Average phase compositions determined by SEM/EDS analysis (error $\pm 2.0 \%$ ) for a top and bottom slice taken from an SS-15Zr-2Tc alloy. Results are in at.\%.

\begin{tabular}{|c|c|c|c|c|c|c|c|c|c|}
\hline Sample & Phase & $\mathrm{Si}$ & $\mathrm{Cr}$ & $\mathrm{Mn}$ & $\mathrm{Fe}$ & $\mathrm{Ni}$ & $\mathrm{Zr}$ & $\mathrm{Mo}$ & $\mathrm{Tc}$ \\
\hline Bottom & Ferrite & 0.4 & 23.5 & 1.6 & 66.2 & 5.3 & $\mathrm{Neg}{ }^{*}$ & 1.2 & 1.6 \\
\hline Top & Ferrite & 0.5 & 23.4 & 1.6 & 67.1 & 5.2 & $\mathrm{Neg}$. & 1.2 & 1.0 \\
\hline Bottom & Austenite & 0.6 & 17.8 & 1.9 & 66.4 & 11.3 & $\mathrm{Neg}$. & 0.7 & 1.3 \\
\hline Top & Austenite & 0.6 & 17.9 & 1.7 & 67.4 & 10.7 & $\mathrm{Neg}$. & 0.8 & 0.7 \\
\hline Bottom & $\mathrm{Zr}(\mathrm{Fe}, \mathrm{Cr}, \mathrm{Ni}) 2+\mathrm{x}$ & 1.4 & 5.7 & 1.6 & 45.4 & 23.9 & 20.2 & 0.7 & 1.0 \\
\hline Top & $\mathrm{Zr}(\mathrm{Fe}, \mathrm{Cr}, \mathrm{Ni}) 2+\mathrm{x}$ & 1.6 & 5.7 & 1.6 & 46.3 & 23.1 & 20.5 & 0.5 & 0.5 \\
\hline Bottom & (Fe,Cr,Ni)23Zr6 & 1.3 & 8.4 & 1.0 & 51.7 & 19.1 & 17.6 & Neg. & 0.9 \\
\hline Top & (Fe,Cr,Ni)23Zr6 & 1.3 & 8.6 & 0.9 & 52.4 & 18.2 & 18.0 & Neg. & 0.5 \\
\hline
\end{tabular}

Immersion Testing

As described in the introduction the purpose of the immersion testing is two-fold, to assess the release behavior of the technetium and to determine whether or not this release behavior changed with variations in the composition of the alloy. The changes in composition investigated were: 1) the amount of zirconium present, 5,15 or $20 \mathrm{wt} \%, 2$ ) the amount of uranium present, 2 or 5 $w t \%, 3)$ the amount of noble metals present, 0,2 or $4 w t \%$ and 4) the amount of technetium present, $0.5,1$ or $2 \mathrm{wt} \%$. The amount of the major constituent stainless steel was essentially kept constant at $80-93 \mathrm{wt} \%$. The testing results featured here vary in duration from 100 to 500 days due to the differing starting dates of the tests. 
Figure 2 features a typical plot of normalized mass loss (NML) versus elapsed time in days. The composition of this sample is $316 \mathrm{SS} / 15 \mathrm{Zr} / 0.5 \mathrm{Tc}$. The error bars for the vertical axis are left off, but they are $+/-10 \%$ as noted in the experimental section. From this plot several observations can be made. First, the estimated forward reaction rate can be determined by evaluating the slope in the initial time period of approximately 4 weeks. This is a conservative estimate, but it is consistent with that typically obtained by ASTM method C1220-92 [6]. This value is $1.0 \mathrm{E}-3\left(\mathrm{~g} / \mathrm{m}^{2} \mathrm{day}\right)$. Secondly, the longer-term release characteristics of technetium can be determined and a gentler slope can be observed, approximately $2 E-4\left(\mathrm{~g} / \mathrm{m}^{2}\right.$ day) for the time frame evaluated to date (approximately one year). Other samples tested that contained levels of technetium between 0.5 and $2 \mathrm{wt} \%$ Tc displayed similar behavior to that represented in Fig. 1. Values for the estimated forward reaction rate for these other tests will be presented later in this manuscript.

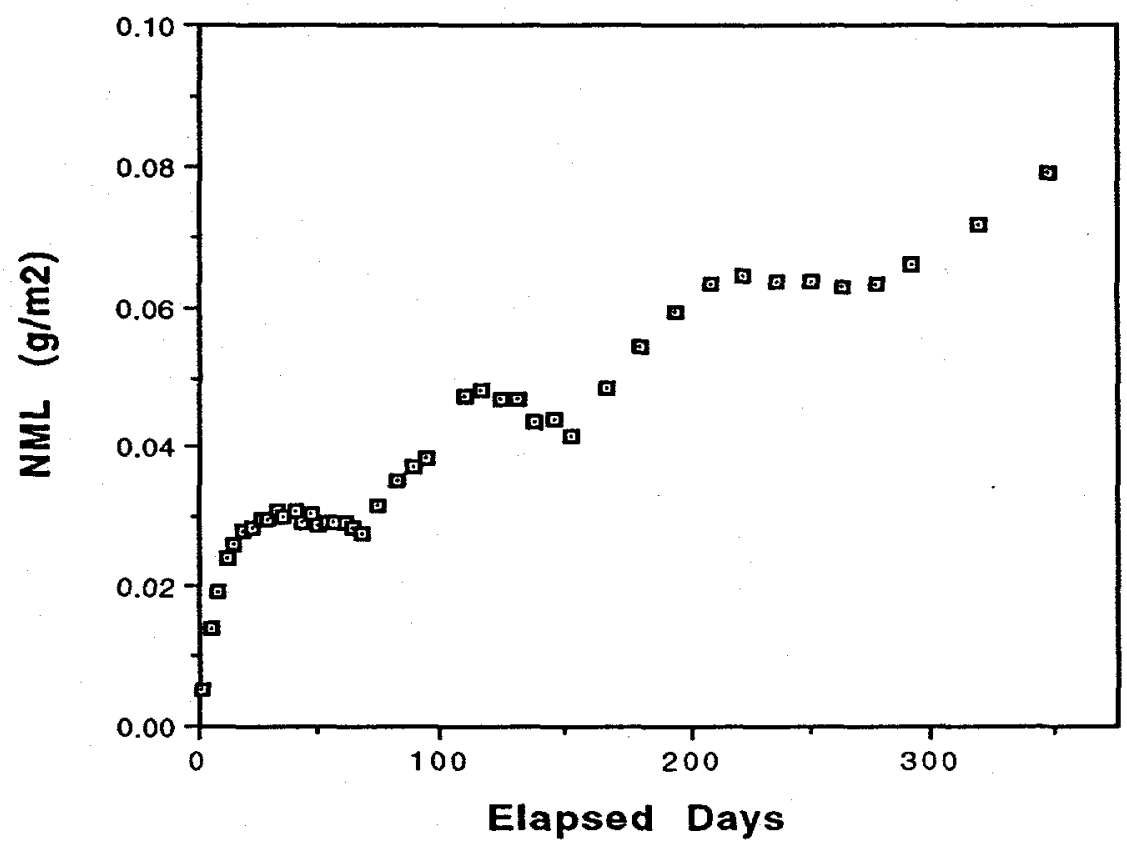

Figure 2. The normalized mass loss of technetium plotted versus elapsed days for a long-term pulsed flow test. The test temperature is $90 \mathrm{C}$ and the SA $/ \mathrm{V}$ ratio is $20 \mathrm{~m}^{-1}$ in a leachate of ASTM type I water. The sample composition is $316 \mathrm{SS} / 15 \mathrm{Zr} / 0.5 \mathrm{Tc}$.

The forward reaction rate indicated here for $\mathrm{Tc}$ release from the simulated metal waste form in ASTM type I water is very low, particularly when compared to the release of Tc from a simulated high level waste glass $[7,8]$. The rate is 3 orders of magnitude less than from the vitrified oxide samples. While one disadvantage of the glass waste is that most of the Tc should be released during the vitrification process via volatilization, since technetium would be present as the more volatile oxide, that which remains is also not immobilized as well as it is with the metal waste form investigated here.

Bradley et al. [7] studied Tc-doped simulated high level waste glass with a variety of leachates, including WIPP Brine, $\mathrm{CaCl}_{2}$ solution, $\mathrm{NaCl}$ solution and $\mathrm{NaHCO}_{3}$ solution. Their test was somewhat different in that the samples were actually glass beads with an approximate diameter 
of $7 \mathrm{~mm}$ with technetium content of $0.5 \mathrm{wt} \%$. However, the SA/V ratio was $10 \mathrm{~m}^{-1}$ which is quite comparable to that used here. The test temperature was $22 \mathrm{C}$ which should lead to a substantially lower rate, however, the reaction rate even when comparing the DI water data to our results is still substantially higher.

The results from tests performed on three samples of differing composition are presented in Fig. 3. The NML for Tc is plotted versus elapsed time in each case. The base alloy is the same for each sample, $316 \mathrm{SS} / 15 \mathrm{Zr}$, with differing amounts of the minor constituents, technetium (0.5-1 $\mathrm{wt} \%)$, noble metals [Ru, $\mathrm{Rh}, \mathrm{Nb}$ and $\mathrm{Pd}](2-4 \mathrm{wt} \%)$ and uranium $(0-2 \mathrm{wt} \%)$. Each test was performed in triplicate with a representative plot being featured in Fig. 4 . The release behavior of Tc over the time span tested, 120 days, does not appear to change with differing compositions within the experimental uncertainty of the test.

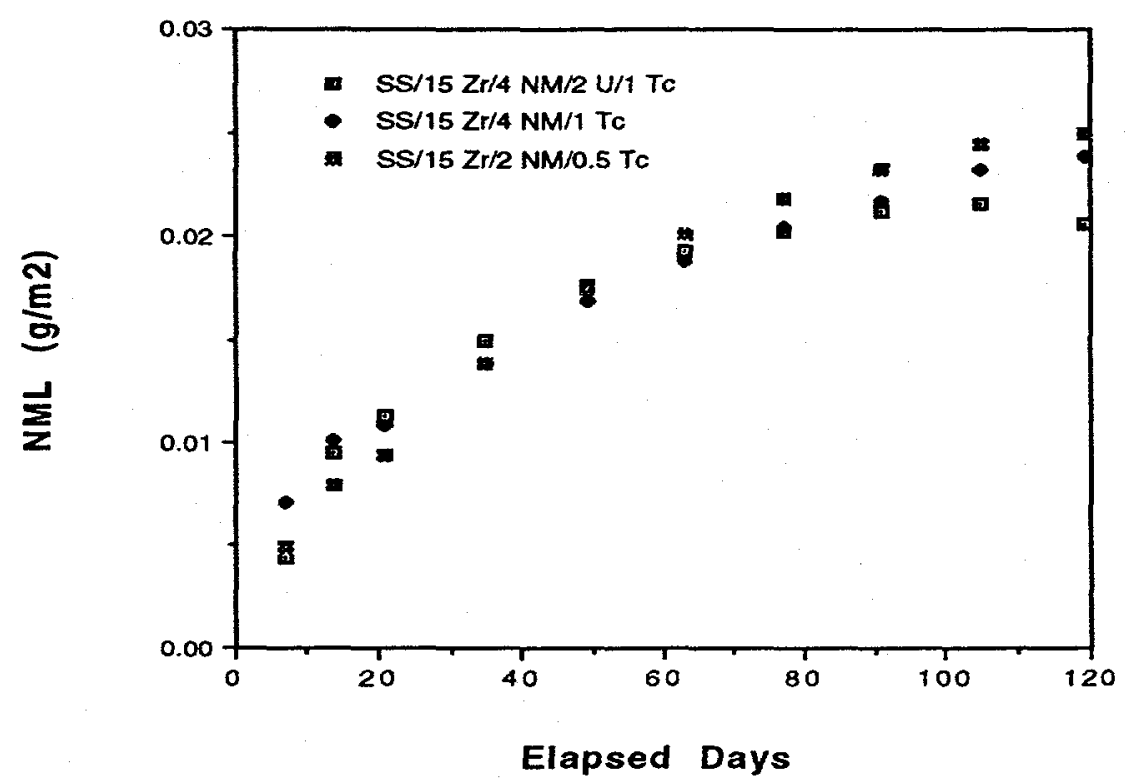

Figure 3. The normalized mass loss of technetium plotted versus elapsed days for three longterm pulsed flow tests. The test temperature is $90 \mathrm{C}$ and the $\mathrm{SA} / \mathrm{V}$ ratio is $50 \mathrm{~m}^{-1}$ in a leachate of SJ-13 water. The sample composition is noted in the figure, except that $2 \mathrm{NM}$ means $0.5 \mathrm{wt} \%$ each of $\mathrm{Ru}, \mathrm{Rh}, \mathrm{Nb}$ and $\mathrm{Pd}$ while $4 \mathrm{NM}$ means $1.0 \mathrm{wt} \%$ each of $\mathrm{Ru}, \mathrm{Rh}, \mathrm{Nb}$ and $\mathrm{Pd}$.

The negligible change of the release rate of technetium with rather substantially different amounts of noble metals present is a significant result. These changes in the noble metal fission products can be brought about by many different physical processes such as: 1) variable conditions in the electrorefiner used to treat the fuel [2],2) differing burnup conditions in the fuel and 3) the treatment of a different fuel type. The point being that the performance of the metal waste form is insensitive to such occurrences. This is a very attractive feature for the metal waste form.

It is also pertinent to note other similar work on waste forms that were developed to immobilize technetium $[9,10]$. Synroc $C$ was developed for application to the HLW streams emanating from reprocessing plants. These streams are known to contain a variety of fission products including Tc. It is very interesting that for a Synroc waste form containing $2 \mathrm{wt} \% \mathrm{Tc}, \mathrm{Tc}$ is observed to be present in the reduced form in combination with other elements such as $\mathrm{Mo}, \mathrm{Pd}, \mathrm{Rh}, \mathrm{Te}, \mathrm{Fe}$ and 
$\mathrm{Ni}$ as submicron sized inclusions which are encapsulated by the primary titanate phases of the Synroc $[9,10]$. This may be the closest reference against which to compare the performance of the metal waste form. Even though the waste forms appear to be very different, a tailored ceramic versus a metal, the form of the Tc-containing phase in both waste forms is, in fact, a metal alloy. The immersion tests performed on the Tc-containing Synroc $\mathrm{C}$ were of a similar type to those presented here. They were at $90 \mathrm{C}$, performed on a monolithic sample for extended periods of time with data gathered as the experiment progressed. The initial rates observed for Tc release are featured in Table II. It was observed that the rate of release of Tc diminished with time with results presented out to approximately 200 days. The conditions utilized for the results presented here should be considered to be oxic.

Table III. Tc release rates from Ref. 8 and 9.

\begin{tabular}{|l|l|l|l|l|l|}
\hline $\begin{array}{l}\text { Release } \\
\text { Rate } \\
\left(\mathrm{g} / \mathrm{m}^{2} \text { day }\right)\end{array}$ & Test Conditions & Ref. & $\begin{array}{l}\text { Release } \\
\text { Rate } \\
\left(\mathrm{g} / \mathrm{m}^{2} \text { day }\right.\end{array}$ & Test Conditions & Ref. \\
\hline $5 \mathrm{E}-2$ & 7 day, MCC-1, DI water & {$[9]$} & $5 \mathrm{E}-3$ & $\begin{array}{l}28 \text { day, MCC-1, } \mathrm{pH} 6.1 \\
\text { buffer, oxic conditions }\end{array}$ & {$[8]$} \\
\hline $2 \mathrm{E}-3$ & $\begin{array}{l}28 \text { day, MCC-1, DI water, } \\
\text { oxic conditions }\end{array}$ & {$[8]$} & $6 \mathrm{E}-4$ & $\begin{array}{l}28 \text { day, MCC-1, DI } \\
\text { water, anoxic } \\
\text { conditions }\end{array}$ & {$[8]$} \\
\hline $1 \mathrm{E}-5$ & $\begin{array}{l}28 \text { day, MCC-1, DI water, } \\
\text { anoxic conditions }\end{array}$ & {$[8]$} & & & \\
\hline
\end{tabular}

The comparison of the results obtained for Synroc $C$ versus those obtained for the simulated metal waste form are very favorable. The simulated metal waste form immobilizes $\mathrm{Tc}$ as well as synroc $\mathrm{C}$ based on the early forward reaction rates and comparable at longer times (several hundred days). The comparison is perhaps more valid than that with glass where the $T c$ is clearly present as an oxide, a different chemical form.

\section{CONCLUSIONS}

Interim long-term immersion results were presented for technetium spiked simulated metal waste forms from Argonne Nation Laboratory's electrometallurgical treatment process. The release rates obtained were less than or equal to $5 \mathrm{E}-3\left(\mathrm{~g} / \mathrm{m}^{2}\right.$ day) for both technetium and uranium. All the forward reaction rates measured as a part of this study are presented in Table IV. These compared very favorably against those for simulated HLW glass containing Tc and comparably for those obtained for Synroc $C$ containing Tc. Variations in the noble metal content, zirconium content and technetium content had negligible effect on the release rates for technetium and uranium from those alloys. The metal waste form currently under development appears to be robust in nature and very durable. 
Table IV. The estimated forward reaction rates for the various alloys tested. The analytes that the reaction rate is based on are noted in parenthesis for each group of samples.

\begin{tabular}{|l|l|l|}
\hline Sample Id. & $\begin{array}{l}\text { Estimated Forward } \\
\text { Reaction Rate }\left(\mathrm{g} / \mathrm{m}^{2} \text { day }\right)\end{array}$ & Leachate \\
\hline $\mathrm{SS} / 15 \mathrm{Zr} / 2 \mathrm{Tc}$ & $1 \mathrm{E}-3(\mathrm{Tc})$ & ASTM Type I water \\
\hline $\mathrm{SS} / 15 \mathrm{Zr} / 0.5 \mathrm{Tc}$ & $1 \mathrm{E}-3(\mathrm{Tc})$ & ASTM Type I water \\
\hline $\mathrm{SS} / 5 \mathrm{Zr} / 2 \mathrm{U}$ & $1 \mathrm{E}-3(\mathrm{U})$ & $\mathrm{SJ}-13$ water \\
\hline $\mathrm{SS} / 15 \mathrm{Zr} / 2 \mathrm{U}$ & $1 \mathrm{E}-3(\mathrm{U})$ & $\mathrm{SJ}-13$ water \\
\hline $\mathrm{SS} / 20 \mathrm{Zr} / 2 \mathrm{U}$ & $1 \mathrm{E}-3(\mathrm{U})$ & $\mathrm{SJ}-13$ water \\
\hline $\mathrm{SS} / 15 \mathrm{Zr} / 5 \mathrm{U}$ & $3 \mathrm{E}-3(\mathrm{U})$ & $\mathrm{SJ}-13$ water \\
\hline $\mathrm{SS} / 15 \mathrm{Zr} / 2 \mathrm{NM} / 0.5 \mathrm{Tc}$ & $6 \mathrm{E}-4(\mathrm{Tc})$ & $\mathrm{SJ}-13$ water \\
\hline $\mathrm{SS} / 15 \mathrm{Zr} / 4 \mathrm{NM} / 1 \mathrm{Tc}$ & $6 \mathrm{E}-4(\mathrm{Tc})$ & $\mathrm{SJ}-13$ water \\
\hline $\mathrm{SS} / 15 \mathrm{Zr} / 4 \mathrm{NM} / 2 \mathrm{U} / 1 \mathrm{Tc}$ & $6 \mathrm{E}-4(\mathrm{Tc}), 5 \mathrm{E}-3(\mathrm{U})$ & $\mathrm{SJ}-13$ water \\
\hline
\end{tabular}

\section{ACKNOWLEDGMENTS}

Argonne National Laboratory is operated for the US Department of Energy by the University of Chicago. This work was supported by the US Department of Energy, Reactor Systems, Development and Technology, under contract W-31-109-ENG-38. The following individuals are acknowledged for their valuable assistance: J. R. Krsul (preparation of technetium for castings), K. Teraguichi and R. Elliot (preparation of sample ingots) and E. L. Wood (preparation of samples for immersion tests).

\section{REFERENCES}

[1] Ackerman, J. P., McDeavitt, S. M., Pereira, C., Simpson, L. J., ANS Proceedings "Third Topical Meeting DOE Spent Nuclear Fuel and Fissile Materials Management", Charleston, SC, 699 (1998).

[2] Prog. Nucl. Energy, 31 (1997).

[3] Barkatt, Aa., Macedo, P. B., Gibson, B. C., Mowad, R., Sousanpour, W., Barkatt, Al., Boroomand, M. A., AdelHadadi, M. Rogers, V. L., Waste Management '85, Vol. 1, 471 (1985).

[4] Barkatt, Aa., Macedo, P. B., Sousanpour, W., Barkatt, Al., Boroomand, M. A., Fisher, C. F., Shirron, J. J., Szoke, P., Rogers, V. L., Nucl. and Chem. Waste Management, 4, 153 (1983).

[5] Mendel, J. E., ed., Final Report of the Defense High-Level Waste Leaching Mechanisms Program, PNL-5157 (1984).

[6] C1220-92, "Static Leaching of Monolithic Waste For Disposal of Radioactive Waste", ASTM, Philadelphia (1995).

[7] Bradley, D. J., Harvey, C. O., Turcotte, R. P., "Leaching of Actinides and Technetium from Simulated HighLevel Waste Glass", PNL-3152 (1979).

[8] Fortner, J. A., Bates, J. K., Mat. Res. Soc., 412, 205 (1997).

[9] Hart, K. P., Vance, E. R., Day, R. A., Begg, B. D., Angel, P. J., Jostens, A., Mat. Res. Soc., 412, 281 (1997).

[10] Ringwood, A. E., Kesson, S. E., Reeve, K. D. Levins, D. M., Ramm, E. J., in "Radioactive Waste Forms for the Future", W. Lutze and R. C. Ewing, eds., North-Holland, Amsterdam, 233 (1988). 